\title{
Fluxes of methane, carbon dioxide and nitrous oxide in an alpine wetland and an alpine grassland of the Tianshan Mountains, China
}

\author{
GuiXiang $\mathrm{HE}^{1,3}$, KaiHui $\mathrm{LI}^{1 *}$, XueJun LIU ${ }^{1,2}$, YanMing GONG ${ }^{1}$, YuKun HU \\ ${ }^{1}$ Key Laboratory of Biogeography and Bioresource in Arid Land, Xinjiang Institute of Ecology and Geography, Chinese \\ Academy of Sciences, Urumqi 830011, China; \\ ${ }^{2}$ College of Resources and Environmental Sciences, China Agricultural University, Beijing 100193, China; \\ ${ }^{3}$ University of Chinese Academy of Sciences, Beijing 100049, China
}

\begin{abstract}
Methane $\left(\mathrm{CH}_{4}\right)$, carbon dioxide $\left(\mathrm{CO}_{2}\right)$ and nitrous oxide $\left(\mathrm{N}_{2} \mathrm{O}\right)$ are known to be major greenhouse gases that contribute to global warming. To identify the flux dynamics of these greenhouse gases is, therefore, of great significance. In this paper, we conducted a comparative study on an alpine grassland and alpine wetland at the Bayinbuluk Grassland Eco-system Research Station, Chinese Academy of Sciences. By using opaque, static, manual stainless steel chambers and gas chromatography, we measured the fluxes of $\mathrm{CH}_{4}, \mathrm{~N}_{2} \mathrm{O}$ and $\mathrm{CO}_{2}$ from the grassland and wetland through an in situ monitoring study from May 2010 to October 2012. The mean flux rates of $\mathrm{CH}_{4}, \mathrm{~N}_{2} \mathrm{O}$ and $\mathrm{CO}_{2}$ for the experimental alpine wetland in the growing season (from May to October) were estimated at $322.4 \mathrm{\mu g} /\left(\mathrm{m}^{2} \cdot \mathrm{h}\right), 16.7 \mathrm{\mu g} /\left(\mathrm{m}^{2} \cdot \mathrm{h}\right)$ and $76.7 \mathrm{mg} /\left(\mathrm{m}^{2} \cdot \mathrm{h}\right)$, respectively; and the values for the alpine grassland were $-88.2 \mu \mathrm{g} /\left(\mathrm{m}^{2} \cdot \mathrm{h}\right), 12.7 \mu \mathrm{g} /\left(\mathrm{m}^{2} \cdot \mathrm{h}\right), 57.3 \mathrm{mg} /\left(\mathrm{m}^{2} \cdot \mathrm{h}\right)$, respectively. The gas fluxes showed large seasonal and annual variations, suggesting weak fluxes in the non-growing season. The relationships between these gas fluxes and environmental factors were analyzed for the two alpine ecosystems. The results showed that air temperature, precipitation, soil temperature and soil moisture can greatly influence the fluxes of $\mathrm{CH}_{4}, \mathrm{~N}_{2} \mathrm{O}$ and $\mathrm{CO}_{2}$, but the alpine grassland and alpine wetland showed different feedback mechanisms under the same climate and environmental conditions.
\end{abstract}

Keywords: alpine wetland; alpine grassland; $\mathrm{CH}_{4} ; \mathrm{N}_{2} \mathrm{O} ; \mathrm{CO}_{2}$; Tianshan Mountains

Citation: GuiXiang HE, KaiHui LI, XueJun LIU, YanMing GONG, YuKun HU. 2014. Fluxes of methane, carbon dioxide and nitrous oxide in an alpine wetland and an alpine grassland of the Tianshan Mountains, China. Journal of Arid Land, 6(6): 717-724. doi: 10.1007/s40333-014-0070-0

Methane $\left(\mathrm{CH}_{4}\right)$, carbon dioxide $\left(\mathrm{CO}_{2}\right)$ and nitrous oxide $\left(\mathrm{N}_{2} \mathrm{O}\right)$ are dominant greenhouse gases (Wan et al., 2013), contributing to about $60 \%, 20 \%$ and $6 \%$ of the global warming potential, respectively (IPCC, 2007). Identifying the sources and sinks of greenhouse gases (GHGs) in terrestrial ecosystems has become an important global research concern (Dalal and Allen, 2008; Schrier-Uijl et al., 2010; Merbold et al., 2013). Wetlands regulate the biogeochemical cycling, play a significant role in the global carbon budget and have a great potential for the exchange of greenhouse gases with the atmosphere (Bonneville et al., 2008). Under cool and waterlogged anaerobic conditions, high- latitude wetlands have moderate decomposition rates relative to rates of primary productivity (Trumbore et al., 1999; Hirota et al., 2006). Carbon dynamics in high-latitude wetland ecosystems are thought to respond dramatically to climate changes, such as the temperature and precipitation changes that are predicted to occur under global warming conditions (Oechel et al., 1993).

As a typical temperate arid alpine grassland,

*Corresponding author: KaiHui LI (E-mail: likh@ms.xjb.ac.cn) 
Bayinbuluk alpine grassland is the second largest of its kind in China. Recently, a number of studies in $\mathrm{CH}_{4}, \mathrm{~N}_{2} \mathrm{O}$ and $\mathrm{CO}_{2}$ fluxes have been conducted on grasslands and wetlands (Ma et al., 2012; Morse et al., 2012; Merbold et al., 2013), yet few researches have considered the alpine grasslands and wetlands of the Tianshan Mountains in Xinjiang ( $\mathrm{Li}$ et al., 2012). In order to verify the dynamic fluxes of these gases in alpine wetlands and grasslands, we conducted a series of comparative studies, which will deepen our understanding of greenhouse gas emission processes in alpine wetland and grassland ecosystems. In this paper, we focused on the following two aspects: (1) to compare the variance between the alpine grassland and alpine wetland in $\mathrm{CH}_{4}, \mathrm{~N}_{2} \mathrm{O}$ and $\mathrm{CO}_{2}$ fluxes; and (2) to analyze the impact of meteorological (temperature, precipitation) and environmental variables (air temperature, soil temperature and soil water content at $10-\mathrm{cm}$ depth) on $\mathrm{CH}_{4}, \mathrm{~N}_{2} \mathrm{O}$ and $\mathrm{CO}_{2}$ fluxes.

\section{Materials and methods}

\subsection{Study area}

Our study was conducted in the Bayinbuluk Grassland Eco-system Research Station, Chinese Academy of Sciences, which is situated on the southern slope $(2,500 \mathrm{~m}$ asl) of the Tianshan Mountains, Xinjiang Uygur autonomous region of China. We established our sample plots in an alpine grassland and wetland in the Bayinbuluk region at $42^{\circ} 52.83^{\prime} \mathrm{N}, 83^{\circ} 42.12^{\prime} \mathrm{E}$ and $42^{\circ} 53.02^{\prime} \mathrm{N}, 83^{\circ} 43.28^{\prime} \mathrm{E}$, respectively. The average annual precipitation reaches $265.7 \mathrm{~mm}$, with $78.1 \%$ occurring in the growing season. The annual average temperature is $-4.8^{\circ} \mathrm{C}$, with a lowest monthly value of $-27.4^{\circ} \mathrm{C}$ in January and a highest monthly value of $11.2^{\circ} \mathrm{C}$ in July. Soil freezing-thawing processes occur regularly from early April to early May and from early October to early November. These processes last about one month for each period.

\subsection{Methods}

Flux measurements were conducted in two typical alpine ecosystems (an alpine wetland and alpine grassland) of the Tianshan Mountains, which were grazed under a grazing intensity of $4.3 \mathrm{sheep} / \mathrm{hm}^{2}$. The wetland, which is seasonally inundated, is dominated by Carex melantha. The grassland is dominated by Stipa purpurea. Air samples were collected in a stainless steel airtight chamber with opaque materials at the top $(50 \mathrm{~cm} \times 50 \mathrm{~cm} \times 10 \mathrm{~cm})$. The external surface of each chamber was covered with white plastic foam to minimize the impact of direct radiative heating during sampling. Four replicated chambers were used at each site. Gas from the chamber was sampled at intervals of 0,15 and 30 minutes and after that the chamber was closed and transferred immediately into a pre-evacuated $50-\mathrm{mL}$ air bag using a $60-\mathrm{mL}$ plastic syringe (Hede Inc., Dalian, China). Over the threeyear period from 2010 to $2012, \mathrm{CH}_{4}, \mathrm{~N}_{2} \mathrm{O}$ and $\mathrm{CO}_{2}$ fluxes were sampled four times each month during the growing season (May-October) and twice each month during the non-growing season (November-April), with the exception of several winter months when samples were not collected due to extremely cold weather conditions. $\mathrm{CH}_{4}, \mathrm{~N}_{2} \mathrm{O}$ and $\mathrm{CO}_{2}$ concentrations of the gas samples (stored in specific air bags) were analyzed by gas chromatography (Agilent 4890D, Agilent Technologies, Wilmington, DE) within one week. The calculation of $\mathrm{CH}_{4}, \mathrm{~N}_{2} \mathrm{O}$ and $\mathrm{CO}_{2}$ fluxes were done according to the description of Zhang et al., (2005). Average gas fluxes and standard errors were calculated from four replicates for each site.

Air temperature $\left(\mathrm{T}_{\text {air }}\right)$, soil temperature at $10-\mathrm{cm}$ depth $\left(\mathrm{T}_{\text {soil }}\right)$ and soil water content (SWC) at $10-\mathrm{cm}$ depth were monitored when gas samples were collected. The calculation of average gas fluxes and statistical analysis were carried out with SPSS 12.0 for Windows (SPSS Inc., Chicago, IL) and SigmaPlot version 10 (SyStat Software Inc., San Jose, CA). Linear regression analysis was used to identify significant positive or negative correlations between environmental variables and $\mathrm{CH}_{4}, \mathrm{~N}_{2} \mathrm{O}$ and $\mathrm{CO}_{2}$ fluxes.

\section{Results}

\subsection{Meteorological environment}

Seasonal dynamics of both precipitation and air temperature produced one-peak patterns, which were higher in the growing season and lower in the non-growing season (Fig. 1). The annual precipitations in 2010, 2011 and 2012 were 389.9, 337.5 and $264.4 \mathrm{~mm}$, respectively. Similar with precipitation, 
there were some differences in average annual or seasonal air temperature among 2010, 2011 and 2012. For all the three years, minimum monthly average temperatures were observed in January. The minimum monthly average temperature in $2011\left(-33.5^{\circ} \mathrm{C}\right)$ was significantly lower than those in $2010\left(-23.9^{\circ} \mathrm{C}\right)$ and $2012\left(-25 \cdot 3^{\circ} \mathrm{C}\right)$. All maximum monthly average temperatures were observed in August. The maximum monthly average temperature in $2012\left(16.4^{\circ} \mathrm{C}\right)$ was higher than those in $2011\left(14.6^{\circ} \mathrm{C}\right)$ and $2010\left(11.5^{\circ} \mathrm{C}\right)$.

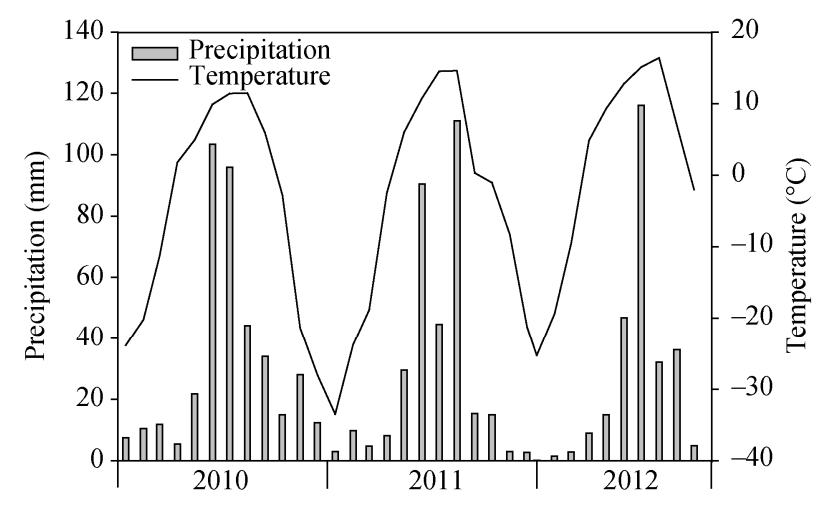

Fig. 1 Monthly mean precipitation and monthly mean air temperature of the study area from 2010 to 2012

\section{2 $\mathrm{CH}_{4}$ fluxes}

The patterns of $\mathrm{CH}_{4}$ emission rates are shown in Fig. 2. The alpine wetlands and alpine grasslands of the Tianshan Mountains serve as the sources and sink of $\mathrm{CH}_{4}$, respectively. $\mathrm{CH}_{4}$ fluxes of the alpine wetland showed obvious and regular seasonal patterns in the study area. The $\mathrm{CH}_{4}$ emissions during the growing season accounted for $92.2 \%$ of the fluxes of the whole year, while the emissions from May to August contributed $87.8 \%$ of the total annual fluxes. Dynamics of the $\mathrm{CH}_{4}$ fluxes in the growing season and cumulative seasonal fluxes are shown in Table 1.

\section{3 $\mathrm{CO}_{2}$ fluxes}

The patterns of $\mathrm{CO}_{2}$ emission rates in growing and non-growing seasons of the alpine grassland and wetland are shown in Fig. 3. The $\mathrm{CO}_{2}$ emission fluxes of the alpine wetland showed large seasonal variations in the study area, and there were significant differences in the $\mathrm{CO}_{2}$ emission rates between the growing season and non-growing season. During the growing season,

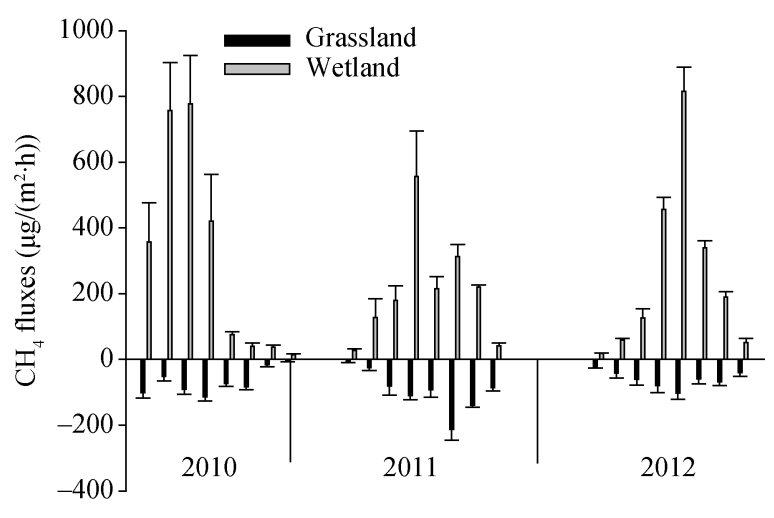

Fig. 2 Monthly average $\mathrm{CH}_{4}$ fluxes in the alpine grassland and wetland of the study area from 2010 to 2012

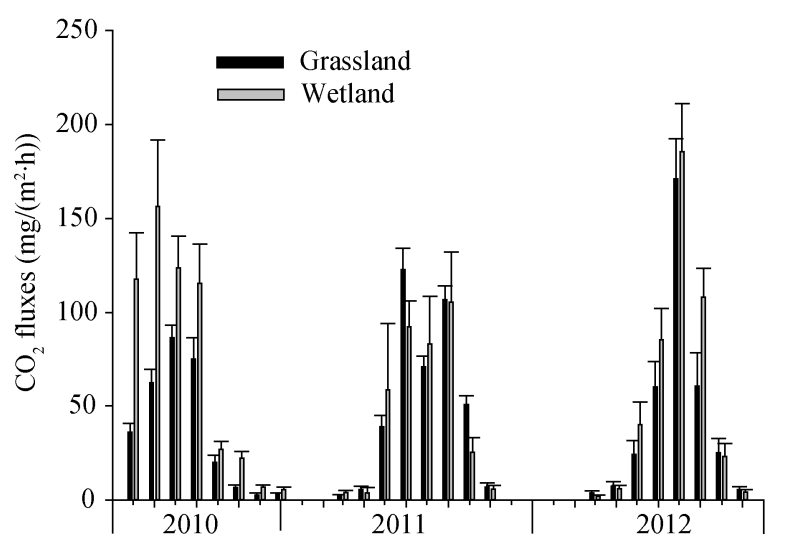

Fig. 3 Monthly average $\mathrm{CO}_{2}$ fluxes in the alpine grassland and wetland of the study area from 2010 to 2012

the $\mathrm{CO}_{2}$ emissions accounted for $96.6 \%$ of the annual fluxes, and emissions from May to August accounted for $88.1 \%$ of the annual fluxes. The $\mathrm{CO}_{2}$ emission fluxes in the alpine grassland also showed fluctuant curve and the peak fluxes observed during growing season. The maximum monthly average $\mathrm{CO}_{2}$ fluxes were $86.7 \pm 6.6,122.8 \pm 11.4$ and $171.2 \pm 45.4 \mathrm{mg} /\left(\mathrm{m}^{2} \cdot \mathrm{h}\right)$ in the three years, respectively. The monthly average $\mathrm{CO}_{2}$ emission fluxes and cumulative annual $\mathrm{CO}_{2}$ emissions also showed large variations. However, $\mathrm{CO}_{2}$ fluxes of the grassland and wetland showed different variations. The cumulative annual $\mathrm{CO}_{2}$ fluxes for 2010 and 2011 were 217.8 and $303.8 \mathrm{~g} / \mathrm{m}^{2}$ (Table 2).

\section{$2.4 \quad \mathrm{~N}_{2} \mathrm{O}$ fluxes}

The grassland and wetland are both sources of $\mathrm{N}_{2} \mathrm{O}$ (Fig. 4). The $\mathrm{N}_{2} \mathrm{O}$ emission fluxes of the grassland and wetland presented large seasonal variations, suggesting 
Table 1 Dynamics of $\mathrm{CH}_{4}$ emission fluxes in the growing season (May to October) and the cumulative seasonal $\mathrm{CH}_{4}$ fluxes

\begin{tabular}{|c|c|c|c|c|c|c|c|}
\hline \multirow{2}{*}{ Land type } & \multirow{2}{*}{ Year } & \multicolumn{3}{|c|}{$\mathrm{CH}_{4}$ emission fluxes $\left(\mu \mathrm{g} /\left(\mathrm{m}^{2} \cdot \mathrm{h}\right)\right)$} & \multicolumn{3}{|c|}{ Cumulative $\mathrm{CH}_{4}$ fluxes $\left(\mathrm{mg} / \mathrm{m}^{2}\right)$} \\
\hline & & Maximum & Minimum & Average & Growing season & Non-growing season & Annual \\
\hline \multirow{4}{*}{ Wetland } & 2010 & $777.1 \pm 146.7$ & $40.5 \pm 9.0$ & $404.7 \pm 290.6$ & $1,632.6$ & 199.2 & $1,831.8$ \\
\hline & 2011 & $556.1 \pm 138.9$ & $41.6 \pm 8.2$ & $254.1 \pm 157.1$ & $1,078.8$ & 139.4 & $1,218.2$ \\
\hline & 2012 & $814.7 \pm 204.4$ & $51.1 \pm 12.3$ & $308.3 \pm 195.0$ & $1,377.3$ & - & - \\
\hline & Average & & & 322.4 & $1,362.9$ & 169.3 & $1,525.0$ \\
\hline \multirow[t]{4}{*}{ Grassland } & 2010 & $-113.4 \pm 13.4$ & $-52.2 \pm 13.8$ & $-85.7 \pm 19.5$ & -339.9 & -61.9 & -401.8 \\
\hline & 2011 & $-212.6 \pm 33.4$ & $-81.3 \pm 27.4$ & $-120.2 \pm 45.5$ & -511.5 & -51.2 & -562.7 \\
\hline & 2012 & $-71.2 \pm 18.9$ & $-39.8 \pm 10.7$ & $-58.6 \pm 10.8$ & -231.5 & - & - \\
\hline & Average & & & -88.2 & -361.0 & -56.6 & -482.3 \\
\hline
\end{tabular}

Table 2 Dynamics of $\mathrm{CO}_{2}$ emission fluxes in the growing season (May to October) and the cumulative seasonal $\mathrm{CO}_{2}$ fluxes

\begin{tabular}{|c|c|c|c|c|c|c|c|}
\hline \multirow{2}{*}{ Land type } & \multirow{2}{*}{ Year } & \multicolumn{3}{|c|}{$\mathrm{CO}_{2}$ emission fluxes $\left(\mathrm{mg} /\left(\mathrm{m}^{2} \cdot \mathrm{h}\right)\right)$} & \multicolumn{3}{|c|}{ Cumulative $\mathrm{CO}_{2}$ fluxes $\left(\mathrm{g} / \mathrm{m}^{2}\right)$} \\
\hline & & Maximum & Minimum & Average & Growing season & Non-growing season & Annual \\
\hline \multirow{2}{*}{ Wetland } & 2010 & $156.5 \pm 35.4$ & $22.3 \pm 3.6$ & $93.8 \pm 50.7$ & 365.3 & 33.0 & 398.3 \\
\hline & 2011 & $105.6 \pm 22.6$ & $5.7 \pm 2.0$ & $61.8 \pm 36.1$ & 260.4 & 30.1 & 290.5 \\
\hline \multirow{6}{*}{ Grassland } & 2012 & $185.5 \pm 49.2$ & $4.3 \pm 1.1$ & $74.4 \pm 41.0$ & 307.1 & - & - \\
\hline & Average & & & 76.7 & 310.9 & 31.6 & 344.4 \\
\hline & 2010 & $86.7 \pm 6.6$ & $6.7 \pm 1.3$ & $47.8 \pm 29.1$ & 194.6 & 25.2 & 217.8 \\
\hline & 2011 & $122.8 \pm 11.4$ & $6.8 \pm 2.4$ & $66.2 \pm 39.6$ & 280.6 & 23.2 & 303.8 \\
\hline & 2012 & $171.2 \pm 45.4$ & $5.5 \pm 1.5$ & $57.8 \pm 34.5$ & 240.8 & - & - \\
\hline & Average & & & 57.3 & 238.7 & 24.2 & 260.8 \\
\hline
\end{tabular}

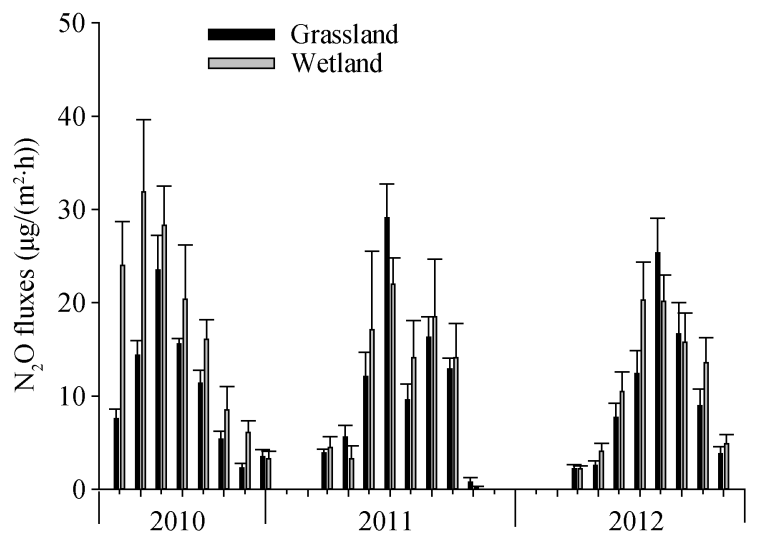

Fig. 4 Monthly average $\mathrm{N}_{2} \mathrm{O}$ fluxes in the alpine grassland and wetland of the study area from 2010 to 2012

a strong source during the growing season and a weak source during the non-growing season. The $\mathrm{N}_{2} \mathrm{O}$ emission fluxes of the grassland and wetland during the growing season accounted for $88.3 \%$ and $83.6 \%$ of the annual fluxes, respectively. The cumulative annual $\mathrm{N}_{2} \mathrm{O}$ emissions were 67.0 and $64.8 \mathrm{mg} / \mathrm{m}^{2}$ in 2010 and 2011, respectively (Table 3).

\subsection{Relationships between $\mathrm{CH}_{4}, \mathrm{CO}_{2}, \mathrm{~N}_{2} \mathrm{O}$ fluxes and environmental variables}

To identify the factors regulating the $\mathrm{CH}_{4}, \mathrm{~N}_{2} \mathrm{O}$ and $\mathrm{CO}_{2}$ fluxes, the relationships between $\mathrm{CH}_{4}, \mathrm{CO}_{2}$, $\mathrm{N}_{2} \mathrm{O}$ fluxes and environmental variables were analyzed for the grassland and the wetland, respectively (Figs. 5 and 6). Linear equations describing $\mathrm{T}_{\text {soil }}$, $\mathrm{T}_{\text {air }}$ and $\mathrm{SWC}$ fitted well to changes of $\mathrm{CH}_{4}$ emissions in the alpine grassland. $\mathrm{T}_{\text {soil }}, \mathrm{T}_{\text {air }}, \mathrm{CO}_{2}$ fluxes and $\mathrm{N}_{2} \mathrm{O}$ fluxes showed positive exponential relationships. With regard to $\mathrm{CO}_{2}$ emissions in the alpine grassland and wetland, both $\mathrm{N}_{2} \mathrm{O}$ and $\mathrm{CO}_{2}$ fluxes showed positive linear correlations with SWC.

\section{Discussion}

In this study, we observed that the alpine grassland absorbed $\mathrm{CH}_{4}$, while the alpine wetland emitted $\mathrm{CH}_{4}$. Tomomichi et al. (2011) reported that the average $\mathrm{CH}_{4}$ emission per unit area from the wetland was at least 
Table 3 Dynamics of $\mathrm{N}_{2} \mathrm{O}$ emission fluxes in the growing season and the cumulative seasonal $\mathrm{N}_{2} \mathrm{O}$ fluxes

\begin{tabular}{|c|c|c|c|c|c|c|c|}
\hline \multirow{2}{*}{ Land type } & \multirow{2}{*}{ Year } & \multicolumn{3}{|c|}{$\mathrm{N}_{2} \mathrm{O}$ emissions fluxes $\left(\mu \mathrm{g} /\left(\mathrm{m}^{2} \cdot \mathrm{h}\right)\right)$} & \multicolumn{3}{|c|}{ Cumulative $\mathrm{N}_{2} \mathrm{O}$ fluxes $\left(\mathrm{mg} / \mathrm{m}^{2}\right)$} \\
\hline & & Maximum & Minimum & Average & Growing season & Non-growing season & Annual \\
\hline \multirow{2}{*}{ Wetland } & 2010 & $31.9 \pm 7.8$ & $8.5 \pm 2.5$ & $21.5 \pm 7.7$ & 86.6 & 18.4 & 105.0 \\
\hline & 2011 & $22.0 \pm 2.8$ & $0.2 \pm 0.1$ & $14.3 \pm 6.9$ & 55.8 & 10.4 & 66.2 \\
\hline \multirow{6}{*}{ Grassland } & 2012 & $29.1 \pm 3.6$ & $4.9 \pm 1.4$ & $14.2 \pm 5.4$ & 59.3 & - & - \\
\hline & Average & & & 16.7 & 67.2 & 14.4 & 81.6 \\
\hline & 2010 & $23.5 \pm 3.7$ & $5.4 \pm 0.8$ & $13.0 \pm 5.9$ & 54.2 & 12.8 & 67.0 \\
\hline & 2011 & $25.3 \pm 7.0$ & $0.8 \pm 0.5$ & $13.5 \pm 8.5$ & 54.1 & 10.7 & 64.8 \\
\hline & 2012 & $20.2 \pm 5.6$ & $3.8 \pm 1.1$ & $12.5 \pm 7.0$ & 52.9 & - & - \\
\hline & Average & & & 12.7 & 53.7 & 11.8 & 65.5 \\
\hline
\end{tabular}

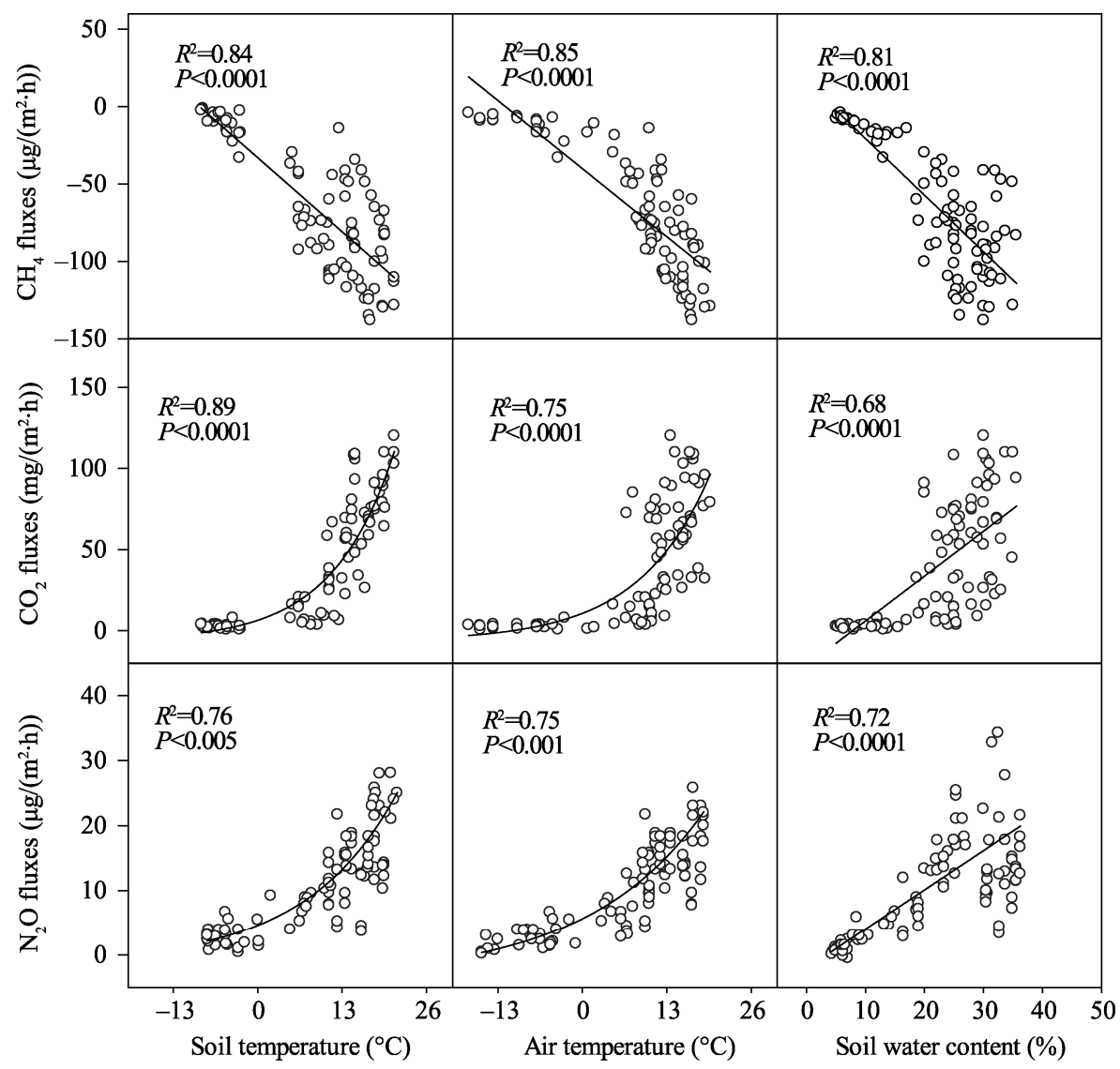

Fig. 5 Relationships between $\mathrm{CH}_{4}, \mathrm{~N}_{2} \mathrm{O}$ and $\mathrm{CO}_{2}$ fluxes and $\mathrm{T}_{\text {soil }}$ at $10-\mathrm{cm}$ soil depth, $\mathrm{T}_{\text {air }}$ and $\mathrm{SWC}$ at 10-cm soil depth of the grassland

100 times larger than the average $\mathrm{CH}_{4}$ uptake per unit area by the grasslands on the Qinghai-Tibet Plateau. In our work, the average $\mathrm{CH}_{4}$ emission from the wetland was normally several (sometimes up to ten) times higher than that from the grassland. The pattern and magnitude of $\mathrm{CH}_{4}$ fluxes in the alpine grassland and wetland were markedly different, which may be attributed to completely different soil moisture condi- tions and different responses of microbial activity in soil substrate to temperature changes (Van den Bos, 2003). For the grassland, $\mathrm{CH}_{4}$ consumption was significantly correlated with air temperature, soil temperature and topsoil $(0-10 \mathrm{~cm})$ moisture. $\mathrm{CH}_{4}$ uptake is determined by two important factors: (1) soil temperature (Daulat and Clymo, 1998), since $\mathrm{CH}_{4}$ oxidation is a microbe-driven process; and (2) gas transport 


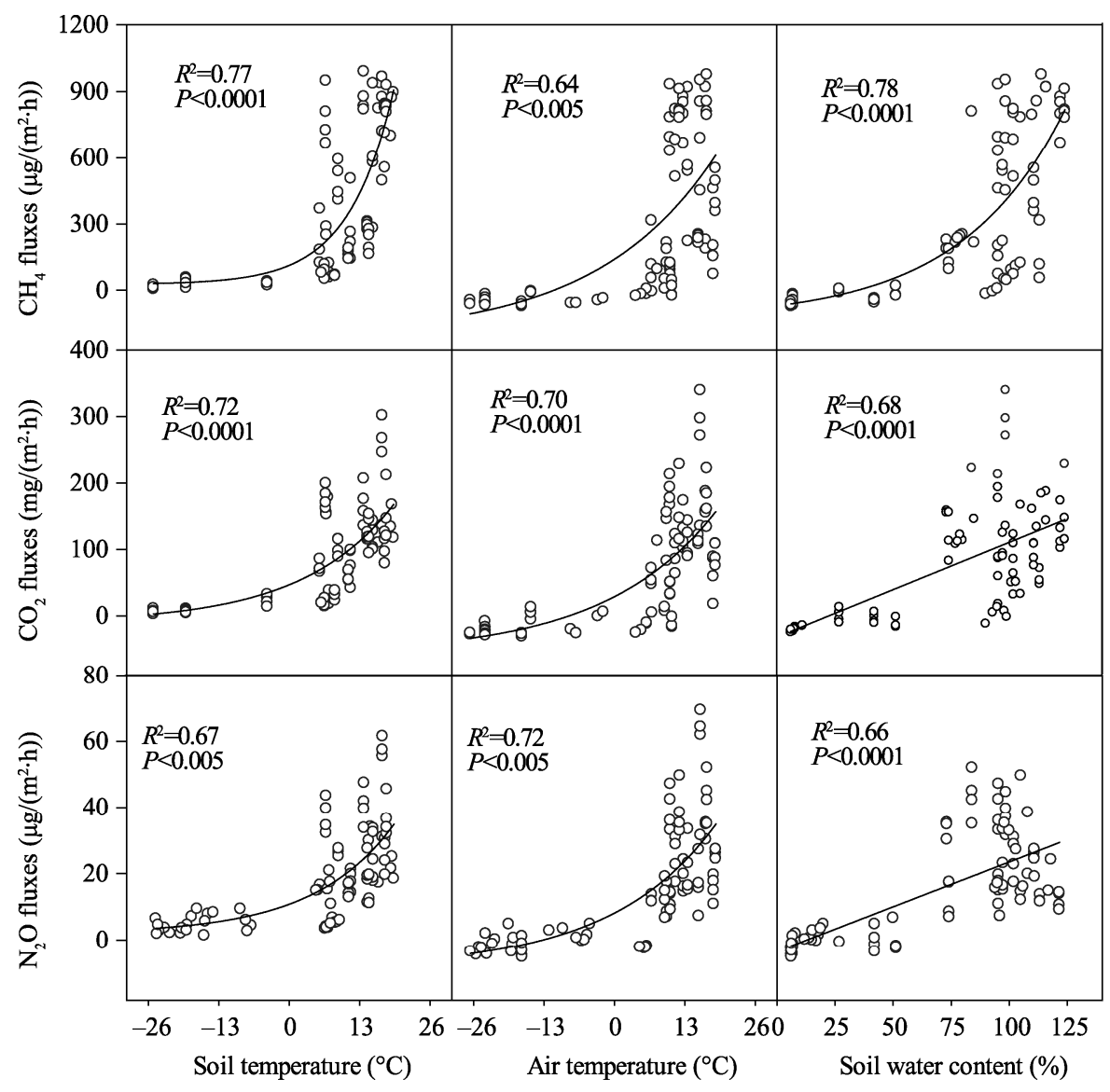

Fig. 6 Relationships between $\mathrm{CH}_{4}, \mathrm{~N}_{2} \mathrm{O}$ and $\mathrm{CO}_{2}$ fluxes and $\mathrm{T}_{\text {soil }}$ at $10-\mathrm{cm}$ soil depth, $\mathrm{T}_{\text {air }}$ and $\mathrm{SWC}$ at 10-cm soil depth of the wetland

resistance, which is influenced by soil wetness and structure. Drier and warmer soil favored $\mathrm{CH}_{4}$ oxidation, and the optimum soil moisture and temperature for $\mathrm{CH}_{4}$ consumption were $21 \%-24 \%$ and $5^{\circ} \mathrm{C}-10^{\circ} \mathrm{C}$, respectively (Castro et al., 1995; Dasselaar et al., 1998). For the wetland, soil moisture and temperature strongly control methane dynamics because $\mathrm{CH}_{4}$ production occurs under anaerobic conditions and thus requires saturated soils (Jones et al., 2005), while $\mathrm{CH}_{4}$ consumption is obligatory aerobic and requires unsaturated soils (Gulledge and Schimel, 1998).

In our study, distinct seasonal variations were observed in $\mathrm{CH}_{4}$ and $\mathrm{CO}_{2}$ fluxes, as well as in precipitation and air temperature. Such seasonal variations were also observed by other researchers (Hirota et al., 2010; Wang et al., 2010; Hao et al., 2011). We attributed these results to the obvious variations in weather conditions at our study sites (Fig. 1). Seasonal changes in $\mathrm{CH}_{4}$ and $\mathrm{CO}_{2}$ fluxes are usually related to air temperature, soil moisture and temperature, soil nutrients, biomass and vegetation types (Jia et al., 2005; Pen-Mouratov et al., 2006). In this study, regression analysis showed that $\mathrm{CO}_{2}$ fluxes were significantly correlated with air temperature as well as with soil temperature and moisture at a $10-\mathrm{cm}$ depth. Our findings are in line with the results of previous reports (Mikha et al., 2005; Gao et al., 2011). Plant productivity and the growth of micro-organisms, which depend heavily on air temperature and variations in climate (Hirota et al., 2004), are relatively low in alpine ecosystems because of the short growing season and severe weather conditions (Körner, 2003). Hence, seasonal changes of climate and environmental factors can contribute to seasonal changes of $\mathrm{CO}_{2}$ fluxes. In our study, $\mathrm{CO}_{2}$ emission rates were lower in grassland soil than in wetland soil, indicating that wetland soil can emit more $\mathrm{CO}_{2}$ than grassland soil. The aboveground biomass in the alpine wetland was much higher than in the alpine grassland because of affluent soil moisture and soil nutrients (Braun et al., 
2013). More plants produce more $\mathrm{CO}_{2}$ through respiration. Humid conditions of wetlands are very conducive to the growth of micro-organisms, which will produce more $\mathrm{CO}_{2}$ through anaerobic respiration. This might be due to the fact that aerobic respiration is more efficient for $\mathrm{CO}_{2}$ emission than anaerobic respiration (Melling et al., 2005).

Average $\mathrm{N}_{2} \mathrm{O}$ fluxes were smaller than those recorded from previous studies conducted in two alpine grasslands, which gave a 3-year average of 39.4-51.6 $\mathrm{N}_{2} \mathrm{O} \mu \mathrm{g} /\left(\mathrm{m}^{2} \cdot \mathrm{h}\right)$ (Du et al., 2008). The $\mathrm{N}_{2} \mathrm{O}$ flux for the alpine grassland was generally stable throughout 2010, 2011 and 2012, and averaged $13.0 \mu \mathrm{g} /\left(\mathrm{m}^{2} \cdot \mathrm{h}\right)$ during growing season. This pattern compared well with the results for the $\mathrm{N}_{2} \mathrm{O}$ fluxes of the wetland, which fluctuated strongly from $21.5 \pm 7.7$ to $14.2 \pm 5.4 \mu \mathrm{g} /\left(\mathrm{m}^{2} \cdot \mathrm{h}\right)$ over the three years. The production of soil $\mathrm{N}_{2} \mathrm{O}$ is primarily the result of micro-organism mediated nitrification and denitrification processes (Bremner, 1997; Barnard et al., 2005; Liu et al., 2007) as well as coupled nitrification and denitrification (Kremen et al., 2005). It was well documented that because both aerobic and anaerobic microsites can be found within soil aggregates (Renault and Stengel, 1994), nitrification and denitrification processes can occur simultaneously in different microsites of the same soil. Therefore, the magnitude of fluxes between soil and atmosphere depends largely on soil temperature, soil water content and $\mathrm{O}_{2}$ availability, and biochemistry processes in substrate (Farquharson and Baldock, 2008). Due to considerable differences in soil chemical property and soil microbial quantity between the alpine grassland and wetland, mechanism of $\mathrm{N}_{2} \mathrm{O}$ production from the two soil types must be different. Therefore, the alpine grassland and wetland performed different seasonal and annual variations.

\section{Conclusions}

The mean flux rates of $\mathrm{CH}_{4}, \mathrm{~N}_{2} \mathrm{O}$ and $\mathrm{CO}_{2}$ for the alpine wetland (from May to October) were estimated to be $322.4 \mu \mathrm{g} /\left(\mathrm{m}^{2} \cdot \mathrm{h}\right), 16.7 \mu \mathrm{g} /\left(\mathrm{m}^{2} \cdot \mathrm{h}\right)$ and $76.7 \mathrm{mg} /\left(\mathrm{m}^{2} \cdot \mathrm{h}\right)$, respectively, in the growing season. The values for the alpine grassland were $-88.2 \mu \mathrm{g} /\left(\mathrm{m}^{2} \cdot \mathrm{h}\right), 12.7 \mu \mathrm{g} /\left(\mathrm{m}^{2} \cdot \mathrm{h}\right)$ and $57.3 \mathrm{mg} /\left(\mathrm{m}^{2} \cdot \mathrm{h}\right)$, respectively. Both the alpine grassland and the alpine wetland showed large sea- sonal and annual variations in greenhouse gas fluxes, suggesting strong fluxes during the growing season and weak fluxes during non-growing periods. The proportions of $\mathrm{CH}_{4}, \mathrm{~N}_{2} \mathrm{O}$ and $\mathrm{CO}_{2}$ fluxes in the wetland during the growing season were $92.2 \%, 96.6 \%$ and $88.3 \%$ of their respective annual total, with $87.8 \%$, $88.1 \%$ and $71.4 \%$ absorbed or emitted from May to August, respectively.

Linear equations describing $\mathrm{T}_{\text {soil }}, \mathrm{T}_{\text {air }}$ and $\mathrm{SWC}$ showed a good fit to $\mathrm{CH}_{4}$ emission changes for the alpine grassland. $\mathrm{T}_{\text {soil }}, \mathrm{T}_{\text {air }}, \mathrm{CO}_{2}$ fluxes and $\mathrm{N}_{2} \mathrm{O}$ fluxes showed positive exponential relationships. With regard to $\mathrm{CO}_{2}$ emissions in the alpine grassland and wetland, both $\mathrm{N}_{2} \mathrm{O}$ and $\mathrm{CO}_{2}$ fluxes showed positive linear correlations with SWC. In the future, further studies should focus on the relative contribution of $\mathrm{N}_{2} \mathrm{O}, \mathrm{CO}_{2}$ and $\mathrm{CH}_{4}$ emissions from alpine grasslands and wetlands to global greenhouse gas budgets and the indirect effects of elevated $\mathrm{N}$ deposition and climate change on greenhouse gas emission in alpine ecosystems.

\section{Acknowledgements}

This work was funded by the National Basic Research Program of China (2009CB825103), the National Natural Science Foundation of China (41340041), the West Light Foundation of the Chinese Academy of Sciences (XBBS201206). The authors would like to express their deep gratitude to the anonymous reviewers for their valuable suggestions that greatly improved the manuscript.

\section{References}

Barnard R, Leadley P W, Hungate B A. 2005. Global change, nitrification, and denitrification: a review. Global Biogeochemical Cycles, doi: 10.1029/2004GB002282.

Bonneville M C, Strachan I B, Humphrey E R, et al. 2008. Net ecosystem $\mathrm{CO}_{2}$ exchange in a temperate cattail marsh in relation to biophysical properties. Agricultural and Forest Meteorology, 148(1): 69-81.

Braun M, Bai Y G, McConkey B, et al. 2013. Greenhouse gas flux in a temperate grassland as affected by landform and disturbance. Landscape Ecology, 28: 709-723.

Bremner J M. 1997. Sources of nitrous oxide in soils. Nutrient Cycling in Agroecosystems, 49(1-3): 7-16.

Castro M S, Steudler P A, Melillo J M, et al. 1995. Factors controlling atmospheric methane consumption by temperate forest soils. Global Biogeochemical Cycles, 9(1): 1-10.

Dalal R C, Allen D E. 2008. Greenhouse gas fluxes from natural ecosystems. Australian Journal of Botany, 56(5): 369-407. 
Dasselaar P A, Beusichem M V, Oenema O. 1998. Effects of soil moisture content and temperature on methane uptake by grassland on sandy soils. Plant and Soil, 204(2): 213-222.

Daulat W E, Clymo R S. 1998. Effects of temperature and watertable on the efflux of methane from peatland surface cores. Atmospheric Environment, 32(19): 3207-3218.

Du Y G, Cui Y G, Xu X L, et al. 2008. Nitrous oxide emissions from two alpine meadows in the Qinghai-Tibetan Plateau. Plant and Soil, 311(1-2): 245-254.

Farquharson R, Baldock J. 2008. Concepts in modelling $\mathrm{N}_{2} \mathrm{O}$ emissions from land use. Plant and Soil, 309(1-2): 147-167.

Gao J Q, Ouyang H, Lei G C, et al. 2011. Effects of temperature, soil moisture, soil type and their interactions on soil carbon mineralization in Zoigê Alpine Wetland, Qinghai-Tibet Plateau. Chinese Geographical Science, 21(1): 27-35.

Gulledge J, Schimel J P. 1998. Moisture control over atmospheric $\mathrm{CH}_{4}$ consumption and $\mathrm{CO}_{2}$ production in diverse Alaskan soils. Soil Biology and Biochemistry, 30(8): 1127-1132.

Hao Y B, Cui X Y, Wang Y F, et al. 2011. Predominance of precipitation and temperature controls on ecosystem $\mathrm{CO}_{2}$ exchange in Zoige alpine wetlands of Southwest China. Wetland, 31(2): 413-422.

Hirota M, Tang Y H, Hu Q W, et al. 2004. Methane emissions from different vegetation zones in a Qinghai-Tibetan Plateau wetland. Soil Biology and Biochemistry, 36(5): 737-748.

Hirota M, Tang Y H, Hu Q W, et al. 2006. Carbon dioxide dynamics and controls in a deep-water wetland on the Qinghai-Tibetan Plateau. Ecosystems, 9(4): 673-688.

Hirota M, Zhang P C, Gu S, et al. 2010. Small-scale variation in ecosystem $\mathrm{CO}_{2}$ fluxes in an alpine meadow depends on plant biomass and species richness. Journal of Plant Research, 123(4): 531-541.

Jia B R, Zhou G S, Wang F R, et al. 2005. Affecting factors of soil microorganism and root respiration. Chinese Journal of Applied Ecology, 16(8): 1547-1552.

Jones S K, Rees R M, Skiba U M, et al. 2005. Greenhouse gas emissions from a managed grassland. Global and Planetary Change, $47(2-4)$ : 201-211.

Körner C. 2003. Alpine Plant Life: Functional Plant Ecology of High Mountain Ecosystems ( $2^{\text {nd }}$ ed.). Berlin: Springer.

Kremen A, Bear J, Havit U, et al. 2005. Model demonstrating the potential for coupled nitrification denitrification in soil aggregates. Environmental Science \& Technology, 39(11): 4180-4188.

Li K H, Gong Y M, Song W, et al, 2012. No significant nitrous oxide emissions during spring thaw under grazing and nitrogen addition in an alpine grassland. Global Change Biology, 18(8): 2546-2554.

Liu X J., Mosier A R, Halvorson A D, et al. 2007. Dinitrogen and $\mathrm{N}_{2} \mathrm{O}$ emissions in arable soils: effect of tillage, $\mathrm{N}$ source and soil moisture. Soil Biology and Biochemistry, 39(9): 2362-2370.
Ma X Z, Zhang Q L. 2012. Temporal variation of soil greenhouse gases fluxes in a cold-temperate Larix gmelinii forest in Inner Mongolia, China. The Journal of Applied Ecology, 23(8): 2149-2156.

Melling L, Hatano R, Goh K J. 2005. Soil $\mathrm{CO}_{2}$ flux from three ecosystems in tropical peatland of Sarawak, Malaysia. Tellus, 57(1): $1-11$.

Merbold L, Steinlin C. 2013. Winter greenhouse gas fluxes $\left(\mathrm{CO}_{2}, \mathrm{CH}_{4}\right.$ and $\mathrm{N}_{2} \mathrm{O}$ ) from a subalpine grassland. Biogeosciences, 10(5): 3185-3203.

Mikha M M, Riceb C W, Millikenc G A. 2005. Carbon and nitrogen mineralization as affected by drying and wetting cycles. Soil Biology and Biochemistry, 37(2): 339-347.

Morse J L, Ardon M, Bernhardt E S, et al. 2012. Greenhouse gas fluxes in southeastern US coastal plain wetland under contrasting land uses. Ecological Applications, 22(1): 264-280.

Mouratov P S, Rakhimbaev M, Steinberger Y. 2006. Spatio-temporal effect on soil respiration in fine-scale patches in a desert ecosystem. Pedosphere, 16(1): 1-9.

Oechel W C, Hastings S J, George V, et al. 1993. Recent change of Arctic tundra ecosystems from a net carbon dioxide sink to a source. Nature, 361(6412): 520-523.

Renault P, Stengel P. 1994. Modeling oxygen diffusion in aggregated soils: anaerobiosis inside the aggregates. Soil Science Society of America Journal, 58(4): 1017-1023.

Schrier-Uijl A P, Kroon P S, Hensen A, et al. 2010. Comparison of chamber and eddy covariance-based $\mathrm{CO}_{2}$ and $\mathrm{CH}_{4}$ emission estimates in a heterogeneous grass ecosystem on peat. Agricultural and Forest Meteorology, 150(6): 825-831.

Tomomichi K, Mitsuru H, Tang Y H,et al. 2011. Spatial variability of $\mathrm{CH}_{4}$ and $\mathrm{N}_{2} \mathrm{O}$ fluxes in alpine ecosystems on the Qinghai-Tibetan Plateau. Atmospheric Environment, 45(31): 5632-5639.

Trumbore S E, Bubier J L, Harden J W, et al. 1999. Carbon cycling in boreal wetland: a comparison of three approaches. Journal of Geophysical Research Atmospheres, 104(D22): 27673-27682.

Van den Bos R M. 2003. Human influence on carbon fluxes in coastal peatlands: process analysis, quantification and prediction. $\mathrm{PhD}$ Dissertation. Amsterdam: VU University.

Wan X H, Wang Y C, Zhou H, et al. 2013. Research of greenhouse gases $\left(\mathrm{CH}_{4}\right.$ and $\left.\mathrm{CO}_{2}\right)$ emission flux in Baiyangdian wetland. Intelligent System Design and Engineering Applications (ISDEA), $1120-1124$.

Wang J, Wang G, Hu H, et al. 2010. The influence of degradation of the swamp and alpine meadows on $\mathrm{CH}_{4}$ and $\mathrm{CO}_{2}$ fluxes on the Qinghai-Tibetan Plateau. Environmental Earth Sciences, 60(3): $537-548$

Zhang J B, Song C C, Yang W. 2005. Cold season $\mathrm{CH}_{4}, \mathrm{CO}_{2}$ and $\mathrm{N}_{2} \mathrm{O}$ fluxes from freshwater marshes in northeast China. Chemosphere, 59(11): 1703-1705. 